\title{
Aplikasi Pengelolaan Bahan Kimia Laboratorium Biologi FMIPA Universitas Tanjungpura
}

\author{
Liza Dahlia $^{\# 1}$, Rudi Dwi Nyoto ${ }^{\# 2}$, Anggi Perwitasari ${ }^{\# 3}$ \\ *Program Studi Teknik Informatika, Universitas Tanjungpura \\ Jl. Prof. Dr. H. Hadari Nawawi, Pontianak 78124 \\ ${ }^{1}$ lizadahlialo@gmail.com \\ ${ }^{2}$ rudydwinyoto@gmail.com \\ ${ }^{3}$ perwitasari.anggiegmail.com
}

\begin{abstract}
Abstrak - Kemajuan teknologi telah membawa dampak perubahan akan tuntutan informasi yang cepat dan akurat serta dinamis dalam pengelolaan data. Pengelolaan data adalah hal rutinitas organisasi sehingga perlu dibudayakan dengan baik dan benar sehingga menghasilkan suatu informasi yang akurat. Laboratorium Jurusan Biologi FMIPA Universitas Tanjungpura saat ini melakukan pengelolaan data bahan kimia secara manual untuk mengerjakan kegiatankegiatan yang berkaitan dengan pengelolaan meliputi pencatatan jumlah dan transaksi bahan kimia sehingga pelayanan yang diberikan kurang optimal. Aplikasi pengelolaan bahan kimia berbasis web dibuat dengan menggunakan bahasa pemrograman PHP, basis data MySQL dan framework laravel, aplikasi pengelolaan dibuat untuk laboratorium biologi MIPA Universitas tanjungpura agar dapat memiliki sistem yang dapat mengelola bahan kimia pada laboratorium. Dari hasil pengujian usability yang telah dilakukan sistem Informasi dapat diimplementasikan karena hasil pengujian sangat baik, terlihat pada akses admin mendapat nilai rata-rata $86 \%$ dan akses ketua laboratorium mendapat nilai rata 91\% sehingga aplikasi dapat diimplementasikan pada laboratorium biologi
\end{abstract}

Kata kunci: pengelolaan, bahan kimia, usability, web

\section{PENDAHULUAN}

Kemajuan teknologi telah membawa dampak perubahan akan tuntutan informasi yang cepat dan akurat serta dinamis dalam pengelolaan data. Pengelolaan data adalah hal rutinitas organisasi sehingga perlu dibudayakan dengan baik dan benar sehingga menghasilkan suatu informasi yang akurat. Pengelolaan data yang konvensional dirasakan kurang relevan lagi dalam menjawab tuntutan organisasi yang semakin dinamis, karena itu harus diperlukan alat yang dapat melakukan tugas-tugas tersebut secara cepat dan akurat yaitu komputer yang mempunyai keunggulan dalam pemrosesan data baik yang harus diolah, disimpan, disajikan, dianalisa ketepatannya dan kecepatan hasil yang dicapai[1].
Laboratorium Jurusan Biologi MIPA Universitas Tanjungpura saat ini pengolahan data bahan kimia masih menggunakan proses secara manual atau belum terkomputerisasi untuk mengerjakan kegiatan-kegiatan yang berkaitan dengan manajemen bahan kimia seperti data inventaris bahan kimia, transaksi bahan kimia dan mengetik laporan-laporan lainnya. Akibatnya proses-proses yang dilakukan secara manual terus menimbulkan beberapa permasalahan

Permasalahan yang pertama yaitu, laboratorium biologi memiliki 21 jenis kegiatan praktikum mata kuliah wajib dan mata kuliah pilihan. Dalam satu hari terdapat 5 mata kuliah praktikum yang setiap mata kuliahnya menghabiskan waktu praktikum lebih dari 3 jam. Kegiatan laboratorium tidak hanya untuk praktikum mahasiswa saja tetapi kegiatan laboratorium digunakan untuk penelitian mahasiswa, penelitian dosen, penelitian kerjasama dari luar dan penelitian untuk proyek atau lomba PKM. Dari padatnya jadwal kegiatan laboratorium tentunya diperlukan proses manajemen bahan kimia secara cepat.

Permasalahan yang kedua adalah pengelolaan persediaan bahan kimia secara manual mengakibatkan adanya kesalahan hitung pada proses pencatatan jumlah bahan kimia yang masuk ke laboratorium maupun keluar dari laboratorium.

Permasalahan ketiga yaitu pengendalian dan perencanaan persediaan bahan kimia yang masih kurang. Banyak ditemukan jenis bahan kimia yang memiliki jumlah persediaan terlalu banyak maupun terlalu sedikit. Hal ini dikarenakan adanya permintaan yang sulit diprediksi sehingga menyebabkan ketimpangan bahan kimia yang terlalu tinggi ataupun rendah.

Berdasarkan permasalahan diatas diangkatlah penelitian berjudul "Aplikasi Pengelolaan Bahan Kimia Laboratorium Biologi FMIPA Universitas Tanjungpura". Sistem ini diharapkan dapat membantu proses pengolahan data persediaan bahan kimia. 


\section{LANDASAN TEORI}

A. Sistem Informasi

Sistem informasi terdiri dari komponen-komponen yang disebut blok bangunan yang terdiri dari blok masukan, blok model, blok keluaran, blok teknologi, blok basis data kendali[2].

\section{B. Framework Laravel}

Framework adalah kerangka kerja yang memudahkan programmer untuk membuat sebuah aplikasi sehingga programmer akan lebih mudah melakukan perubahan (customize) terhadap aplikasinya da $\mathrm{n}$ dapat memakainya kembali untuk aplikasi lain yang sejenis[3].

Laravel adalah framework aplikasi web yang memiliki syntax yang elegan dan ekspresif. Laravel bertujuan untuk membuat proses pembangunan aplikasi yang menyenangkan bagi developer tanpa harus mengorbankan fungsionalitas aplikasi

\section{Teknik Pengujian Perangkat Lunak}

\section{a. Black-box Testing}

Black-Box testing berfokus pada persyaratan fungsional perangkat lunak yang memungkinkan engineers untuk memperoleh set kondisi input yang sepenuhnya akan melaksanakan persyaratan fungsional untuk sebuah program[4].

b. Usability Testing

Usability adalah analisa kualitatif yang menentukan seberapa mudah user menggunakan antarmuka suatu aplikasi. Suatu aplikasi disebut usable jika fungsi-fungsinya dapat dijalankan secara efektif, efisien, dan memuaskan[5].

Tingkat efektivitas dan efisiensi diukur dengan menggunakan user's success rate (tingkat keberhasilan pengguna) yaitu persentase tugas yang telah diselesaikan dengan benar oleh pengguna. Efektivitas dan efisiensi dihitung menggunakan persamaan berikut[6]:

$$
\text { Efektivitas. Efisiensi }(\%)=\frac{\left(\sum_{\mathbf{i}=1}^{\mathbf{n} X i}\right)}{\mathbf{n}} \times \mathbf{1 0 0} \%
$$

Dengan Xi adalah nilai keberhasilan responden ke-i, Xi $=\{0,1\}$.

Kepuasan merupakan persentase perbandingan antara nilai kepuasan responden ke-i(Xi) dengan perkalian antara bobot maksimum skala Likert dengan jumlah responden(n).

$$
\operatorname{Kepuasan}(\%)=\frac{\sum_{\mathbf{i}=1}^{\mathrm{xi}}}{5 \times \mathbf{n}} \times 100 \%
$$

Dengan Xi adalah nilai keberhasilan responden ke-i, Xi $=\{0,1,2,3,4,5\}$.

Usability aplikasi adalah rataan dari efektivitas, efisensi dan kepuasan, seperti tertulis pada persamaan berikut.

$$
\text { usability }=\frac{(\text { Efektivitas }+ \text { Efisiensi }+ \text { Kepuasan })}{3} \times 100 \%
$$

\section{URAIAN PENELITIAN}

A. Gambaran Sistem Usulan

Penelitian dilakukan dengan beberapa tahapan, dimulai dengan studi liteatur, dilanjutkan dengan , analisis kebutuhan, pengumpulan data, perancangan, implementasi, pengujian dan terakhir proses penarikan kesimpulan. Seperti digambarkan pada diagram alir pada Gambar 1

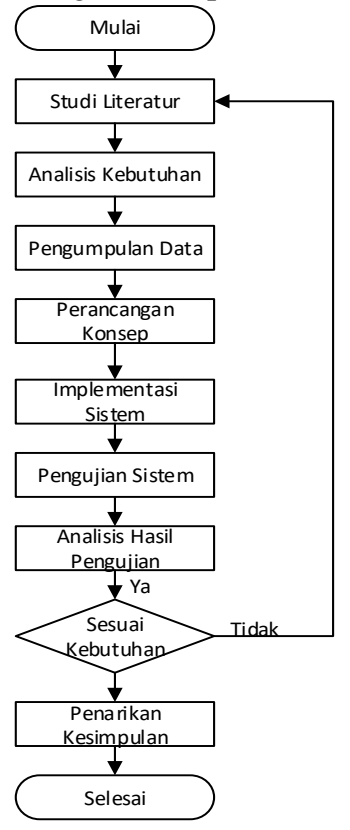

Gambar 1 Diagram Alir Penelitian

\section{B. Sistem Yang Sedang Berjalan}

Sistem yang sedang berjalan pada kegiatan administrasi laboratorium biologi masih menggunakan sistem manual yang dibantu dengan aplikasi microsoft excel dalam pembuatan laporan kegiatan praktikum. Namun data tersebut cukup banyak dan tidak tersimpan secara terpusat dan terstruktur, sehingga menyebabkan data tersebut mudah hilang dan tidak dapat diakses secara online. Sementara itu pada pengisian form kegiatan praktikum mahasiswa, dimulai dari bahan yang digunakan hingga judul percobaan yang dilakukan masih dituliskan oleh masing-masing mahasiswa pada lembaran kegiatan praktikum perharinya, sehingga mengakibatkan lembaran form yang harus dikoreksi oleh seorang laboran sebelum diolah menjadi suatu laporan hasil kegiatan praktikum selama satu semester.

\section{Sistem Yang Diperlukan}

Berdasarkan analisis sistem yang sedang berjalan, maka diperlukan sistem yang dapat mengelola bahan kimia. Pada pendataan bahan kimia diperlukan warning dan laporan yang dapat memberi informasi mengenai tanggal kadaluarsa dan stok bahan kimia. Sistem yang dibangun juga memberikan laporan penerimaan, laporan pemakaian, laporan kadaluarsa, laporan bahan rusak dan laporan stok. 


\section{Diagram Konteks Sistem}

Diagram Konteks adalah diagram yang memberikan gambaran umum terhadap kegiatan yang berlangsung dalam sistem. Gambar 2 berikut menunjukan diagram konteks dari sistem yang dibuat.

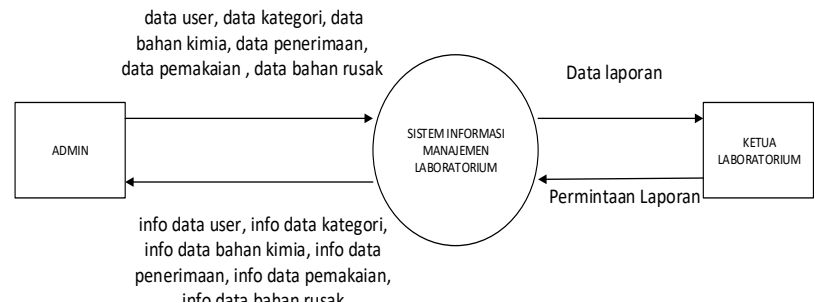

Gambar 2 Diagram Konteks

\section{E. Entity Relationship Diagram}

Adapun entity relationship Diagram dapat dilihat pada Gambar 3 berikut

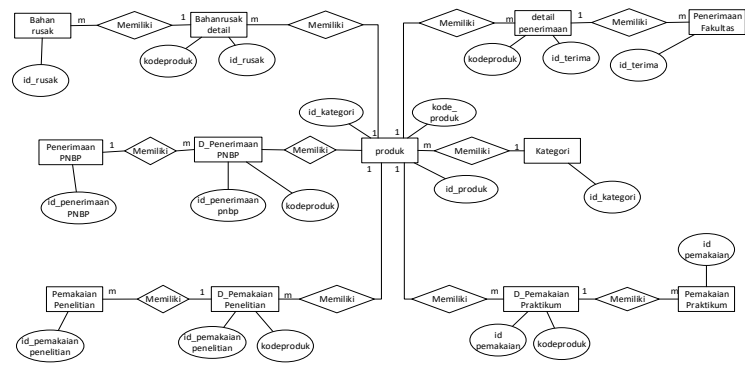

Gambar 3 Entity Relationship Diagram

IV. HASIL DAN ANALISA

\section{A. Antarmuka Aplikasi}

Antarmuka dari hasil perancangan sistem yang telah dibuat adalah seperti terlihat pada gambar 5, gambar 6 dan gambar 7. Halaman transaksi pemakaian praktikum merupakan halaman untuk menambah transaksi pemakaian untuk kegiatan praktikum.

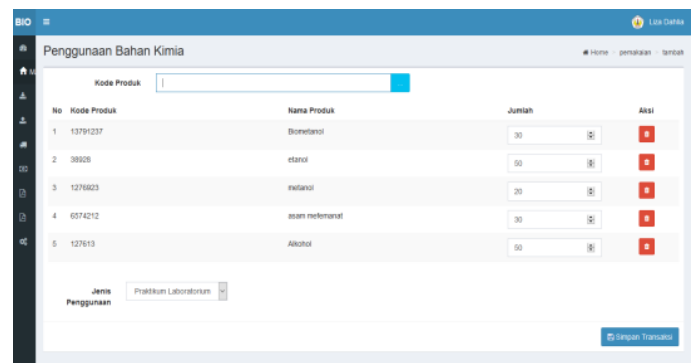

Gambar 5 Halaman pemakaian praktikum

Halaman bahan kimia merupakan halaman untuk menampilkan dan menambahkan produk bahan kimia.

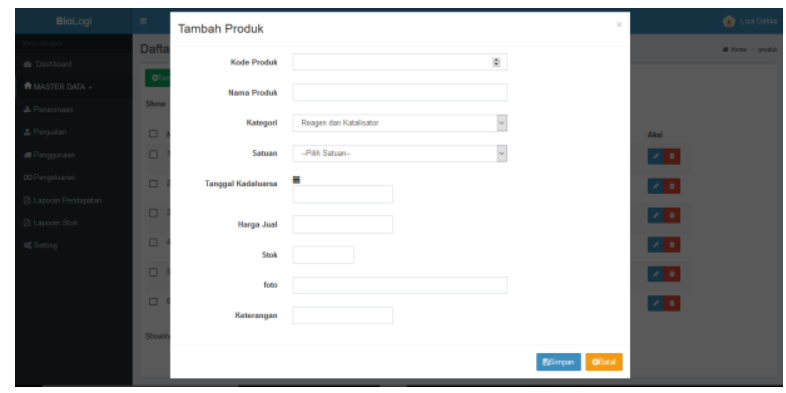

Gambar 6 Form Tambah Bahan Kimia

Laporan stok merupakan halaman untuk menampilkan data stok bahan kimia selama periode satu bulan.

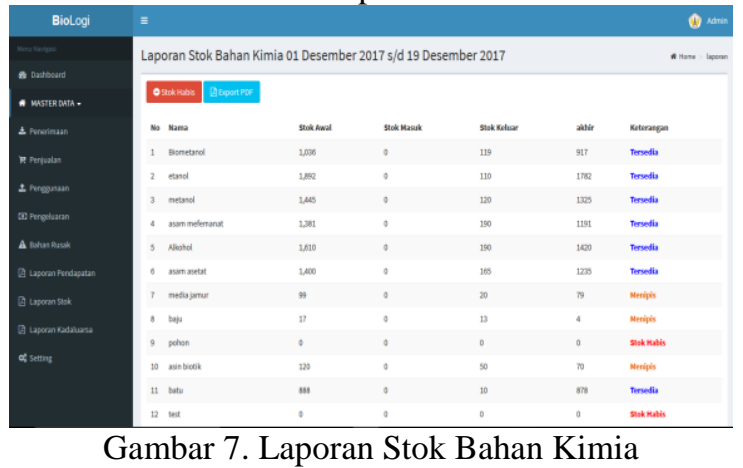

B. Pengujian Sistem

Pengujian dilakukan pada sistem menggunakan metode blackbox dan usability testing.

a. Pengujian BlackBox

Pengujian black box dilakukan untuk mengetahui apakah sistem dan tiap komponennya telah bekerja sesuai fungsinya dari yang telah dirancangkan. Pengujian ini dilakukan untuk mengetahui reaksi sistem terhadap data masukan yang tidak valid. Data yang tidak valid misalnya data yang kosong maupun data masukan yang salah atau tidak sesuai dengan data yang terdapat di dalam tabel.

Tabel 1

Tabel Pengujian fungsi proses login

\begin{tabular}{|l|l|l|l|}
\hline Fungsi & $\begin{array}{l}\text { Contoh } \\
\text { Fungsi }\end{array}$ & $\begin{array}{l}\text { Hasil } \\
\text { Eksekusi }\end{array}$ & Keterangan \\
\hline \multirow{5}{*}{$\begin{array}{l}\text { Pengujian } \\
\text { Login }\end{array}$} & $\begin{array}{l}\text { email dan } \\
\text { password } \\
\text { kosong }\end{array}$ & $\begin{array}{l}\text { Tidak } \\
\text { Berhasil }\end{array}$ & $\begin{array}{l}\text { Harap isi } \\
\text { bidang ini }\end{array}$ \\
\cline { 2 - 4 } & $\begin{array}{l}\text { email salah } \\
\text { Password }\end{array}$ & $\begin{array}{l}\text { Tidak } \\
\text { Berhasil }\end{array}$ & Login Gagal \\
\cline { 2 - 4 } & $\begin{array}{l}\text { Sidak } \\
\text { email dan } \\
\text { password } \\
\text { benar }\end{array}$ & Berhasil & Login Gagal \\
\hline
\end{tabular}


Dari hasil pengujian blackbox pada tabel 1 terlihat bahwa semua pengujian telah sesuai dengan hasil yang diharapkan.

Tabel 2

Tabel pengujian fungsi tambah tambah pemakaian

\begin{tabular}{|c|c|c|c|}
\hline Fungsi & Contoh Fungsi & $\begin{array}{l}\text { Hasil } \\
\text { Eksekusi }\end{array}$ & Keterangan \\
\hline \multirow{3}{*}{$\begin{array}{l}\text { Tambah } \\
\text { Data } \\
\text { Transaksi } \\
\text { Pemakaian } \\
\text { Penelitian }\end{array}$} & $\begin{array}{l}\text { Mengosongkan } \\
\text { kolom produk }\end{array}$ & $\begin{array}{l}\text { Tidak } \\
\text { Berhasil }\end{array}$ & $\begin{array}{l}\text { Produk harus } \\
\text { di isi }\end{array}$ \\
\hline & $\begin{array}{l}\text { Mengosongkan } \\
\text { Jumlah }\end{array}$ & $\begin{array}{l}\text { Tidak } \\
\text { Berhasil }\end{array}$ & $\begin{array}{l}\text { Jumlah harus } \\
\text { di isi }\end{array}$ \\
\hline & $\begin{array}{l}\text { Mengisi } \\
\text { Semua Kolom }\end{array}$ & Berhasil & $\begin{array}{l}\text { Data berhasil } \\
\text { disimpan }\end{array}$ \\
\hline
\end{tabular}

Berdasarkan dari hasil pengujian blackbox pada tabel 2 terlihat bahwa jika mengosongkan beberapa kolom maka tidak berhasil menyimpan transaksi pemakaian, jika mengisi semua kolom maka transaksi berhasil disimpan

\section{b. Pengujian usability}

Berdasarkan hasil implementasi kepada pengguna aplikasi yang ada, pengguna aplikasi akan diamati dan akan diberikan beberapa pertanyaan oleh peneliti, responden akan memberikan tanggapan mengenai aplikasi. Pengujian ini dilakukan pada sisi halaman administrator.

Dari hasil tanggapan yang dihitung, maka akan disesuaikan dengan batasan nilai yang telah ditentukan. Penelitian aplikasi yang di buat termasuk dalam kriteria sangat baik, baik, cukup baik, tidak baik atau sangat tidak baik. Menghitung persentase pada lembar observasi elemen efektifitas dan efisiensi. Perhitungan ini dilakukan dengan merubah kedalam bentuk angka dari setiap jawaban dengan aturan angka 1 (satu) apabila jawaban "Ya" atau tanda centang() dan angka 0 (nol) diberikan kepada jawaban "Tidak". Dari setiap point jawaban benar akan dijumlahkan dan yang terakhir adalah menghitung total persentase dari keseluruhan jawaban yang diberikan. Berikut merupakan hasil pengujian usability elemen efektivitas dan efisiensi:

Tabel 4

Tabel Pengujian akses admin elemen efektifivitas

\begin{tabular}{|r|l|c|}
\hline No. & Pertanyaan & Hasil \% \\
\hline \multicolumn{2}{|l|}{ Skenario untuk membuka sistem (F00) } \\
\hline 1 & Membuka website dengan mudah & 100 \\
\hline 2 & Berhasil membuka Website & 100 \\
\hline 3 & $\begin{array}{l}\text { Membuka menu master data dengan } \\
\text { mudah }\end{array}$ & 33,33 \\
\hline 4 & Berhasil menggunakan tombol tambah & 100 \\
\hline 5 & $\begin{array}{l}\text { Berhasil mengisi data dari setiap menu } \\
\text { master data }\end{array}$ & 100 \\
\hline 6 & $\begin{array}{l}\text { Memahami isi pesan error (jika ada) } \\
\text { dengan mudah }\end{array}$ \\
\hline Fungsi menu penerimaan (F02) \\
\hline
\end{tabular}

\begin{tabular}{|c|c|c|}
\hline 7 & $\begin{array}{l}\text { Membuka menu penerimaan dengan } \\
\text { mudah }\end{array}$ & 66,67 \\
\hline 8 & $\begin{array}{l}\text { Menampilkan data detail penerimaan } \\
\text { denganmudah }\end{array}$ & 100 \\
\hline 9 & Berhasil menggunakan tombol tambah & 100 \\
\hline 10 & Berhasil mengisi data penerimaan & 100 \\
\hline 11 & $\begin{array}{l}\text { Berhasil download nota penerimaan } \\
\text { bentuk pdf }\end{array}$ & 100 \\
\hline 12 & $\begin{array}{l}\text { Memahami isi pesan error (jika ada) } \\
\text { dangan mudah }\end{array}$ & 66,67 \\
\hline \multicolumn{3}{|c|}{ Fungsi menu pemakaian (F03) } \\
\hline 13 & $\begin{array}{l}\text { Membuka menu pemakaian data dengan } \\
\text { mudah }\end{array}$ & 66,67 \\
\hline 14 & $\begin{array}{l}\text { Menampilkan data detail pemakaian } \\
\text { dengan mudah }\end{array}$ & 100 \\
\hline 15 & Berhasil menggunakan tombol tambah & 100 \\
\hline 16 & Berhasil mengisi data pemakaian & 100 \\
\hline 17 & $\begin{array}{l}\text { Berhasil mendownload nota pemakaian } \\
\text { bentuk pdf }\end{array}$ & 100 \\
\hline 18 & $\begin{array}{l}\text { Memahami isi pesan error (jika ada) } \\
\text { dangan mudah }\end{array}$ & 100 \\
\hline \multicolumn{3}{|c|}{ Fungsi menampilkan halaman laporan (F04) } \\
\hline 19 & $\begin{array}{l}\text { Membuka menu halaman dengan } \\
\text { mudah }\end{array}$ & 100 \\
\hline 20 & $\begin{array}{l}\text { Menampilkan data laporan dengan } \\
\text { mudah }\end{array}$ & 100 \\
\hline 21 & Menampilkan data laporan per periode & 100 \\
\hline 22 & Download laporan dalam bentuk PDF & 100 \\
\hline 23 & $\begin{array}{l}\text { Memahami isi pesan error (jika ada) } \\
\text { dengan mudah }\end{array}$ & 100 \\
\hline \multicolumn{2}{|c|}{ Efektifitas } & 92,75 \\
\hline
\end{tabular}

Tabel 5

Tabel pengujian akses admin elemen efisiensi

\begin{tabular}{|r|l|c|}
\hline No & Pertanyaan & Hasil \% \\
\hline \multicolumn{2}{|c|}{ Membuka Sistem (F00) } & 100 \\
\hline 1 & $\begin{array}{l}\text { user mampu Membuka website tanpa } \\
\text { error }\end{array}$ & 100 \\
\hline 2 & $\begin{array}{l}\text { Frekuensi } \text { user bertanya kepada } \\
\text { observator rendah }\end{array}$ & 66,67 \\
\hline 3 & $\begin{array}{l}\text { Frekuensi panduan dan bantuan dari } \\
\text { observator rendah }\end{array}$ & 100 \\
\hline Menginput menu master data (F01) & $\begin{array}{l}\text { User memahami informasi mengenai } \\
\text { aplikasi }\end{array}$ & 33,33 \\
\hline 5 & $\begin{array}{l}\text { Error yang dilakukan } \text { user hanya sedikit } \\
\text { Frekuensi } \text { user bertanya kepada } \\
\text { observator rendah }\end{array}$ & \\
\hline & \multicolumn{2}{|l}{} \\
\hline
\end{tabular}

Korespondensi : Liza Dahlia 


\begin{tabular}{|c|c|c|}
\hline 7 & $\begin{array}{l}\text { Frekuensi panduan dan bantuan dari } \\
\text { observator rendah }\end{array}$ & 0 \\
\hline \multicolumn{3}{|c|}{ Fungsi menu penerimaan(F02) } \\
\hline 8 & $\begin{array}{l}\text { User memahami informasi mengenai } \\
\text { aplikasi }\end{array}$ & 100 \\
\hline 9 & $\begin{array}{l}\text { Pada saat terjadi error atau kesalahan } \\
\text { user dengan mudah mengatasinya }\end{array}$ & 100 \\
\hline 10 & $\begin{array}{l}\text { Error dan kesalahan yang dilakukan } \\
\text { user hanya sedikit }\end{array}$ & 100 \\
\hline 11 & $\begin{array}{l}\text { Frekuensi user bertanya kepada } \\
\text { observator rendah }\end{array}$ & 33,33 \\
\hline 12 & $\begin{array}{l}\text { Frekuensi panduan dan bantuan dari } \\
\text { observator rendah }\end{array}$ & 0 \\
\hline \multicolumn{3}{|c|}{ Fungsi menu pemakaian (F03) } \\
\hline 13 & $\begin{array}{l}\text { User memahami informasi mengenai } \\
\text { aplikasi }\end{array}$ & 100 \\
\hline 14 & $\begin{array}{l}\text { Pada saat terjadi error atau kesalahan } \\
\text { user dengan mudah mengatasinya }\end{array}$ & 100 \\
\hline 15 & $\begin{array}{l}\text { Error dan kesalahan yang dilakukan } \\
\text { user hanya sedikit }\end{array}$ & 100 \\
\hline 16 & $\begin{array}{l}\text { Frekuensi user bertanya kepada } \\
\text { observator rendah }\end{array}$ & 100 \\
\hline 17 & $\begin{array}{l}\text { Frekuensi panduan dan bantuan dari } \\
\text { observator rendah }\end{array}$ & 100 \\
\hline \multicolumn{3}{|c|}{ Fungsi menu laporan (F04) } \\
\hline 19 & $\begin{array}{l}\text { User memahami informasi mengenai } \\
\text { aplikasi }\end{array}$ & 100 \\
\hline 20 & $\begin{array}{l}\text { Frekuensi } \text { user bertanya kepada } \\
\text { observator rendah }\end{array}$ & 100 \\
\hline 21 & $\begin{array}{l}\text { Frekuensi panduan dan bantuan dari } \\
\text { observator rendah }\end{array}$ & 100 \\
\hline \multicolumn{2}{|c|}{ Efisiensi } & 77,77 \\
\hline
\end{tabular}

Setelah semua tugas dikerjakan, respoden diminta memberi penilaian terhadap aplikasi melalui post task kuesioner. Post task kuesioner terdiri dari 10 pertanyaan yang relevan, kepuasan pengguna diukur menggunakan skala likert 1- 5, yang masing-masing jawaban diberi score (nilai) atau bobot yaitu banyaknya score antara 1 sampai 5 , dengan rincian sebagai berikut:

1. Jawaban SS (Sangat Setuju) diberi nilai 5

2. Jawaban $\mathrm{S}$ (Setuju) diberi nilai 4

3. Jawaban $\mathrm{N}$ (Netral/ragu) diberi nilai 3

4. Jawaban TS (Tidak Setuju) diberi nilai 2

5. Jawaban STS (Sangat Tidak Setuju) diberi nilai 1

Tabel 6

Tabel pengujian akses admin elemen kepuasan

\begin{tabular}{|l|l|c|}
\hline No & Pertanyaan & Hasil \% \\
\hline 1 & Aplikasi ini mudah untuk dipelajari & 86,67 \\
\hline 2 & $\begin{array}{l}\text { Terdapat fitur aplikasi yang cukup } \\
\text { merepotkan }\end{array}$ & 73,33 \\
\hline
\end{tabular}

\begin{tabular}{|l|l|c|}
\hline 3 & $\begin{array}{l}\text { Sepertinya akan membutuhkan bantuan } \\
\text { seorang teknisi menggunakan aplikasi }\end{array}$ & 73,33 \\
\hline 4 & $\begin{array}{l}\text { Bahasa yang digunakan mudah } \\
\text { dimengerti }\end{array}$ & 100 \\
\hline 5 & $\begin{array}{l}\text { Fitur-fitur aplikasi ini sudah terintegrasi } \\
\text { dengan baik }\end{array}$ & 86,67 \\
\hline 6 & $\begin{array}{l}\text { Terlalu banyak ketidak konsistenan } \\
\text { dalam aplikasi ini }\end{array}$ & 80 \\
\hline 7 & $\begin{array}{l}\text { Aplikasi ini dapat mengelola data bahan } \\
\text { kimia dengan baik }\end{array}$ & 100 \\
\hline 8 & $\begin{array}{l}\text { Orang-orang akan sangat cepat bisa } \\
\text { menggunakan aplikasi ini }\end{array}$ & 86,67 \\
\hline 9 & $\begin{array}{l}\text { Perlu banyak hal terlebih dahulu } \\
\text { sebelum mulai menggunakan aplikasi ini }\end{array}$ & 86,67 \\
\hline 10 & $\begin{array}{l}\text { Menu yang dibutuhkan yang belum } \\
\text { terdapat pada halaman ini }\end{array}$ & 86,67 \\
\hline Kepuasan & 86 \\
\hline
\end{tabular}

Tabel kuantitatif untuk hasil perhitungan terhadap kuesioner pada Usability Testing untuk mengukur pemakaian website pengelolaan bahan kimia laboratorium biologi Universitas Tanjungpura yaitu [7]:

Tabel 3

Tabel kuantitatif usability testing

\begin{tabular}{|c|l|l|}
\hline Skor & Kualifikasi & Hasil \\
\hline $85-100 \%$ & Sangat Baik (SB) & Berhasil \\
\hline $65-84 \%$ & Baik (B) & Berhasil \\
\hline $55-64 \%$ & Cukup (C) & Tidak Berhasil \\
\hline $0-54 \%$ & Kurang (C) & Tidak Berhasil \\
\hline
\end{tabular}

Dari perhitungan persentase jawaban responden pada usability testing pada tabel 4, 5 dan 6 terhadap kegunaan hak akses admin yang didapat setiap responden dengan kualifikasi sangat baik. Seluruh responden mendapat hasil perhitungan dengan interpretasi dengan sangat baik yaitu $85,5 \%$ dari setiap elemen efektifitas sebesar $92,75 \%$, elemen efisiensi sebesar $77,77 \%$, kepuasan $86 \%$.

\section{Analisis Hasil Pengujian}

a. Analisis Pengujian Akses Admin

Hasil eveluasi efektivitas menyatakan bahwa beberapa fungsi nilai efektivitas rendah seperti membuka menu master data, membuka menu penerimaan dan membuka menu pemakaian hal ini dikarenakan responden kesulitan menemukan tombol navigasi menu pada sidebar.

Hasil evaluasi efisiensi menunjukan bahwa terdapat beberapa fungsi nilai efisiensinya rendah. Pada fungsi F01, responden banyak bertanya dan meminta bantuan observator mengenai tombol navigasi. Pada fungsi F02, responden banyak bertanya dan meminta bantuan kepada observator ketika memilih tombol tambah produk karena responden tidak mengenali tombol tambah produk untuk transaksi 
penerimaan. Pada fungsi F03, responden lancar menggunakan aplikasi karena responden sudah mulai memahami menggunakan aplikasi. Pada fungsi F04, responden lancar menggunakan aplikasi dan tidak banyak bertanya.

Hasil evaluasi kepuasan responden menunjukan sebesar $85,5 \%$. Tingkat kepuasan yang paling rendah adalah fitur aplikasi yang cukup merepotkan dan responden membutuhkan seorang teknisi untuk menggunakan aplikasi yaitu sebesar 73,33\% dibandingkan dengan tingkat kepuasan fungsi lainnya. Hal ini dikarenakan responden baru pertama kali mencoba aplikasi sehingga masih belum terlalu memahami penggunaan aplikasi.

b. Analisis Pengujian Akses Ketua Laboratorium

Hasil eveluasi efektivitas menyatakan bahwa beberapa fungsi nilai efektivitas tinggi hal ini berarti aplikasi yang digunakan sudah sangat baik.

Hasil evaluasi efisiensi menunjukan bahwa terdapat beberapa fungsi nilai efisiensinya rendah. Pada fungsi F04, responden banyak bertanya dan banyak membutuhkan bantuan kepada observator ketika memilih tombol ubah periode karena responden tidak mengenali tombol ubah periode hal ini dikarenakan responden baru pertama kali menggunakan aplikasi.

Hasil evaluasi kepuasan responden menunjukan sebesar $95,33 \%$. Tingkat kepuasan yang paling rendah adalah orangorang akan sangat cepat menggunakan aplikasi yaitu sebesar $86,66 \%$ dibandingkan dengan tingkat kepuasan fungsi lainnya. Hal ini dikarenakan responden baru pertama kali mencoba aplikasi sehingga masih belum terlalu memahami penggunaan aplikasi

\section{KESIMPULAN DAN SARAN}

A. Kesimpulan

1. Sistem ini mampu memberikan informasi dan mengelola bahan kimia laboratorium biologi FMIPA Universitas Tanjungpura

2. Berdasarkan hasil pengujian terhadap Aplikasi Pengelolaan Bahan Kimia Laboratorium di Jurusan Biologi MIPA Universitas Tanjungpura dengan menggunakan metode usability bahwa aplikasi telah berhasil dikembangkan dan berfungsi semestinya dengan tingkat kesesuaian kebutuhan terhadap pengujian fungsional usability elemen efektifitas, efisiensi dan kepuasan admin dan ketua laboratorium sebesar 85,55\% dan $91 \%$.

B. Saran

Adapun beberapa hal yang dapat dilakukan untuk pengembangan aplikasi adalah:

1. Perlu pengembangan aplikasi seperti menambahkan daftar alat laboratorium agar pemanfaatan bisa lebih luas.

2. Untuk penelitian selanjutnya ditambahkan fitur jadwal penggunaan laboratorium.
3. Dapat diintegrasikan dengan berbagai laporan yang sesuai dengan kebutuhan dalam bentuk diagramdiagram.

4. Dapat ditambahkan halaman profil laboratorium.

\section{Daftar Pustaka}

[1] Ferliansyah, Deni. 2016. Sistem Informasi Laboratorium Farmasi dan Biologi Farmasi Fakultas Kedokteran Universitas Tanjungpura. Jurnal Edukasi dan Penelitian Informatika, Vol. 1, No. 1, Universitas Tanjungpura, Pontianak.

[2] Andrika, Yuyi. Sistem Informasi Pemberian Beasiswa Dana APBD Kota di SMP PGRI 3 Pangkalpinang. Pangkalpinang, Indonesia: Jurnal Sistem dan Teknologi Informasi, Vol. 3, No. , 2017.

[3] Rosa A.S. dan M. Shalahuddin. 2013. Rekayasa Perangkat Lunak. Bandung: Informatika.

[4] Pressman, Roger S. 2010. Software Engineering : a practitioner's approach. New York: McGraw-Hill

[5] Nielsen J. 1993. Usability Engineering. San Francisco: Morgan Kaufmann.

[6] Nielsen J. 2001. Success rate: the simplest usability metric. [Internet].[diunduh 2013 Jul 8]. Tersedia pada http://www.nngroup.com/articles/success-rate-thesimplest-usability-metric/.

[7] Arikunto, S. 2009. Prosedur Penelitian Suatu Pendekatan Praktik. Edisi Revisi 6. Jakarta : Rineka Cipta 